\title{
What should we prepare for the next coronavirus disease 2019 outbreak? A survey on the opinions of infectious diseases specialists in South Korea
}

\author{
Bongyoung Kim ${ }^{1,}$, Se Yoon Park ${ }^{2,}$, Dong Sik Jung ${ }^{3}$, Sook In Jung ${ }^{4}$, Won Sup Oh5 ${ }^{5}$, Shin-Woo Kim ${ }^{6}$, \\ Kyong Ran Peck ${ }^{7}$, Hyun-Ha Chang ${ }^{6}$, and The Korean Society of Infectious Diseases
}

\begin{abstract}
${ }^{1}$ Department of Internal Medicine, Hanyang University College of Medicine, Seoul; ${ }^{2}$ Division of Infectious Diseases, Department of Internal Medicine, Soonchunhyang University Seoul Hospital, Seoul; ${ }^{3}$ Division of Infectious Diseases, Department of Internal Medicine, Dong-A University College of Medicine, Busan; ${ }^{4}$ Department of Infectious Diseases, Chonnam National University Medical School, Gwangju; ${ }^{5}$ Division of Infectious Diseases, Department of Internal Medicine, Kangwon National University Hospital, Chuncheon; ${ }^{6}$ Division of Infectious Diseases, Department of Internal Medicine, School of Medicine, Kyungpook National University, Daegu; ${ }^{7}$ Division of Infectious Diseases, Samsung Medical Center, Sungkyunkwan University School of Medicine, Seoul, Korea
\end{abstract}

Received: May 13, 2020 Revised : June 6, 2020 Accepted: June 12, 2020

\section{Correspondence to} Hyun-Ha Chang, M.D.

Division of Infectious Diseases, Department of Internal Medicine, School of Medicine, Kyungpook National University, 130 Dongdeok-ro, Jung-gu, Daegu 41944, Korea

Tel: +82-53-200-6553

Fax: +82-53-426-2046

E-mail: changhha@knu.ac.kr https://orcid.org/oooo-00029405-2121

*These authors contributed equally to this work.

Background/Aims: This study aimed to collect information on the opinions of Korean infectious disease (ID) experts on coronavirus disease 2019 (COVID-19) and related issues in preparation for a future outbreak.

Methods: A survey was conducted over the course of 5 days (from April 21 to 25, 2020), targeting all adult ID specialists currently in the medical field in South Korea $(n=265)$. An online-based survey was forwarded via text message and e-mail. Only one response was accepted from each participant.

Results: Of these 265 ID specialists gotten to, 132 (49.8\%) responded. The highest proportion of the respondents envisaged the current COVID-19 outbreak to end after December 2020 (47.7\% for the domestic Korean outbreak and $70.5 \%$ for the global pandemic); moreover, $60.7 \%$ of them stated that a second nationwide wave is likely to occur between September and December 2020 in South Korea. N95 respirators were considered to be the most important item in hospitals in preparation for a second wave. The most important policy to be implemented at the national level was securing national hospitals designated for the treatment of ID $(67.4 \%)$.

Conclusions: ID experts in South Korea believe that the COVID-19 pandemic may not be easily controlled and that a second nationwide wave is likely to occur in South Korea. Our results indicate that Korean ID specialists believe that a high level of preparation is needed in various aspects, including the procurement of personal protective equipment, to respond efficiently to a second outbreak.

Keywords: COVID-19; Communicable diseases; Korea

\section{INTRODUCTION}

The coronavirus disease 2019(COVID-19) has spread rapidly across the globe since late 2019, resulting in the onset of a pandemic on March 11, 2020. As a result, more than 4 million confirmed cases of COVID-19 have been reported, encom- passing more than 210 countries as of the end of April, $2020[1]$. The first confirmed patient, a Chinese national, entered the country from Wuhan, China on January 19, 2020 [2], and South Korea became one of the first countries to be affected by the outbreak, with a total of 10738 infections as of April 27, 2020 [3]. The highest lev- 
el of infectious disease (ID) alert was declared after the occurrence of a significant outbreak within a religious group in Daegu and its neighboring areas in mid-February 2020 [4], after which several countermeasures were introduced and reinforced. Consequently, the outbreak was mitigated from mid-April, with only around 10 newly confirmed cases per day [3]. Thus, South Korea is revisiting the measures put in place during the worst period of the outbreak, namely social distancing, and is preparing for a return to normal life.

Despite the positive social atmosphere, many experts have been warning of a possible second wave. Considering the characteristics of the severe acute respiratory syndrome coronavirus 2 (SARS-CoV-2), which is reported to be shed from infected patients at the early phase of the COVID-19 and can be transmitted from asymptomatic patients or patients with vague symptoms, it is prospected hard to be controlled [5-7]. Therefore, a discussion on the preparation for the next COVID-19 outbreak might be necessary in order to protect the social system from collapse.

This study aimed to collect information on the opinions of ID experts on COVID-19 and related issues in preparation for a potential second wave of infections.

\section{METHODS}

A questionnaire was designed by three investigators (B.K., S.Y.P., and H.H.C.) based on the 'COVID-19 Real-Time Barometer Study' and modified to reflect the current unsolved issues associated with COVID-19 [8]. The other authors of this study reviewed the draft questionnaire, and it was refined on the SurveyMonkey platform (Supplementary material 1). The questions about the opinions on COVD-19-related issues consisted of four categories: (1) prospects of the COVID-19 outbreak, (2) preparation for a future COVID-19 outbreak, (3) therapeutic options for COVID-19, and (4) miscellaneous. Some questions required the respondent to select multiple answers. The survey was conducted over a period of 5 days (from April 21 to 25) in 2020, and targeted all physicians with a board certificate of adult ID in South Korea $(n=275)$. At the time of the survey, 10 experts were either retired or had passed away and were excluded accordingly. Eventually, 265 ID specialists were identified as the subjects of the survey. A link to the online-based survey was forwarded to the subjects via text message and e-mail. To encourage participation, reminders were sent on the $3 \mathrm{rd}, 4$ th, and 5 th day. There was no reward for the completion of the questionnaire. The respondents were anonymized and were requested to enter their own identification number in order to distinguish duplicated answers. Only one response was accepted from each participant.

In addition to the main analysis, we performed a subgroup analysis for the opinions on the preparation for future COVID-19 outbreak as per the attending physician's experience in treating COVID-19 patients. The confidence interval for differences of binomial proportions was measured using the Agrestic-Caffo method.

All statistical analyses were performed using SPSS version 24.o for Windows (IBM Corp., Armonk, NY, USA). Categorical variables were analyzed using the chi-square test or Fisher's exact test, as appropriate. A two-tailed $p$ value of $<0.05$ was considered statistically significant.

The Institutional Review Board of the Hanyang University Seoul Hospital approved the study protocol (IRB number: 2020-04-039). Online-written informed consent was obtained from participants.

\section{RESULTS}

\section{Demographic characteristics of respondents}

Among the 265 ID specialists, 132 (49.8\%) responded. The mean age of the respondents was $42.8 \pm 6.6$ years, with an average of $8.9 \pm 6.0$ years elapse since they had acquired their ID board certificates and $57.6 \%$ were female. Almost all the respondents (99.3\%) were working at secondary-care or tertiary-care hospitals; the majority (75.8\%) were working at a national or private universityaffiliated hospital. The proportion of respondents who had treated COVID-19 patients as an attending physician was $68.2 \%$ (Table 1 ).

\section{Opinions of ID specialists on COVID-19 related issues}

Table 2 shows the results of our survey. Most respondents stated that they envisaged the current COVID-19 outbreak to end after December 2020 (47.7\% for the domestic outbreak and $70.5 \%$ for the global pandemic), as 
Table 1. Demographic characteristics of respondents $(n=132)$

\begin{tabular}{|c|c|}
\hline Characteristic & Value \\
\hline Age & $42.8 \pm 6.6$ \\
\hline $\begin{array}{l}\text { Length of working experience in } \\
\text { infectious diseases }\end{array}$ & $8.9 \pm 6.0$ \\
\hline Female sex & $76(57.6)$ \\
\hline \multicolumn{2}{|l|}{ Position in the hospital } \\
\hline Director of the clinical department & $60(45 \cdot 4)$ \\
\hline Director of infection control & $52(39.4)$ \\
\hline \multicolumn{2}{|l|}{ Type of hospital by referral system } \\
\hline Tertiary-care hospital & $74(56.1)$ \\
\hline Secondary-care hospital & $57(43.2)$ \\
\hline Hospital & $1(0.7)$ \\
\hline \multicolumn{2}{|l|}{ Type of hospital } \\
\hline National university-affiliated hospital & $24(18.2)$ \\
\hline Private university-affiliated hospital & $76(57.6)$ \\
\hline Public hospital; not university-affiliated & $9(6.8)$ \\
\hline Private hospital; not university-affiliated & $22(16.7)$ \\
\hline \multicolumn{2}{|l|}{ Number of hospital beds } \\
\hline Less than 300 & $4(3 \cdot 0)$ \\
\hline $300-600$ & $27(20.5)$ \\
\hline $600-900$ & $52(39.4)$ \\
\hline $900-1,200$ & $24(18.2)$ \\
\hline More than 1,200 & $25(18.9)$ \\
\hline \multicolumn{2}{|l|}{ Location of the hospital } \\
\hline Seoul/Incheon/Gyeonggi-do & $84(63.6)$ \\
\hline usan/Ulsan/Gyeongsangnam-do & $16(12.1)$ \\
\hline Daegu/Gyeongsangbuk-do & $10(7.6)$ \\
\hline Daejeon/Sejong/Chungchung-do & $9(6.8)$ \\
\hline Gwangju/Jeolla-do & $9(6.8)$ \\
\hline Gangwon-do & $3(2.3)$ \\
\hline Jeju-do & $1(0.8)$ \\
\hline \multicolumn{2}{|l|}{$\begin{array}{l}\text { No. of patients with COVID-19 treated by } \\
\text { attending physicians }\end{array}$} \\
\hline o & $42(31.8)$ \\
\hline $0-10$ & $52(39 \cdot 4)$ \\
\hline $10-50$ & $24(18.2)$ \\
\hline More than 50 & $14(10.6)$ \\
\hline
\end{tabular}

Values are presented as mean \pm SD or number (\%). COVID-19, coronavirus disease 2019 . well as a second nationwide wave in South Korea between September and December 2020 (60.7\%). Accordingly, the majority believed that the current preventive strategies being implemented in Korean hospitals need to be maintained even after December 2020 (43.2\%).

N95 respirators were considered to be the most important item for hospitals in preparation for a second wave, followed by isolation units and hooded coveralls. Furthermore, $75.0 \%$ of the respondents believed that the reuse of $\mathrm{N}_{95}$ respirators might be necessary in the case of a shortage. In the case of a shortage of ventilators, $47.0 \%$ believed that patients should be prioritized based on the likelihood of their recovery. In preparation for another outbreak, the respondents believed that the most important areas of research and development to be fostered were the development of effective vaccines (75.0\%), the development of effective therapeutic drugs (56.8\%), and the development of rapid and accurate diagnostic testing methods (52.3\%). The most important policies to be implemented at the national level included securing national hospitals designated for the treatment of ID (67.4\%), strengthening immigration policies or prohibiting the entry of individuals from affected countries (65.9\%), and maintaining social distancing (46.2\%). Most of the respondents (88.6\%), as concerns the screening of asymptomatic individuals for the prevention COVID-19 outbreaks in medical institution, answered that real-time reverse-transcriptase polymerase chain reaction testing would be necessary for patients with a recent history of visits to affected countries or regions, in order to prevent outbreaks occurring within hospitals. The respondents stated that the most important measures to be upheld by the general public after the end of the outbreak were thorough hand hygiene (74.2\%), followed by avoiding public spaces if one has symptoms of COVID-19 (70.5\%), and the wearing of masks in public (56.8\%). The most recommended type of mask for use on a daily basis was the surgical mask (53.8\%).

In terms of treatment options, the respondents reported that remdesivir was the most promising (81.8\%) therapeutic agent for the treatment of COVID-19, followed by convalescent plasma (65.9\%) and hydroxychloroquine or chloroquine $(49.2 \%)$. The majority of respondents showed a preference towards the use of hydroxychloroquine or chloroquine regimens in the elderly or in severe cases, while prophylactic use was not preferred. 
Kim B, et al. Expert opinions on COVID-19

Table 2. Opinions of infectious diseases specialists on COVID-19-related issues

\begin{tabular}{lc}
\hline Variable & $\%(95 \%$ CI $)$ \\
\hline Prospects of the COVID-19 outbreak & 132 \\
Q1. The expected date of the end of the current domestic COVID-19 epidemic & $12.9(7.6-18.9)$ \\
May-June 2020 & $18.9(12.9-25.8)$ \\
July-August 2020 & $10.6(5.3-16.7)$ \\
September-December 2020 & $47.7(38.7-56.8)$ \\
After December 2020
\end{tabular}

Q2. The expected date of the end of the current global COVID-19 pandemic

May-June 2020

0

July-August 2020

September-December 2020

After December 2020

Q3. The expected date of the occurrence of a second wave nationwide in South Korea

Unlikely

May-June 2020

July-August 2020

September-December 2020

After December 2020

Q4. The expected date of the end of preventive measures to the inflow of COVID-19 into hospitals (e.g., operating COVID-19 screening clinics, safe clinics for respiratory

patients, pre-emptive isolation for pneumonia, etc.)

May-June 2020

July-August 2020

September-December 2020

After December 2020

Depends on the situation

Q5. The date of the termination of social distancing measures

No longer needed

Within 4 weeks from now ${ }^{\mathrm{a}}$

Within 4-8 weeks from now ${ }^{\mathrm{a}}$

More than 8 weeks from now ${ }^{\mathrm{a}}$

Depends on the situation

Preparation for a future COVID-19 outbreak

Q1 ${ }^{\mathrm{b}}$. Crucial items that will be needed in hospitals in preparation for a second wave of COVID-19

N95 respirators

Isolation units (including negative-pressure units)

Hooded coveralls

PAPR equipment (including hoods)

Professional COVID-19 physician

Professional COVID-19 nursing personnel

Infection control personnel

Other protective gear (goggles, hair caps, etc.)

Equipment for oxygen supplementation (including ventilators, high-flow $\mathrm{O}_{2}$ )
$6.8(3.0-11.4)$

$9.8(5.3-15.2)$

$70.5(62.9-78.0)$

$6.8(3.0-11.4)$

$25.8(18.9-33.3)$

$3.8(0.8-7.6)$

$60.6(52.3-68.2)$

$3.0(0.8-6.1)$
$26.5(18.9-34.1)$

$14.4(9.1-20.5)$

$5.3(1.5-9.1)$

$43.2(34.8-51.5)$

$10.6(6.1-15.9)$

$1.5(0-3.8)$

$45.5(37.1-53.0)$

$7.6(3.0-12.1)$

$37.1(28.8-45.5)$

$8.3(3.8-12.9)$

132

$70.5(62.9-78.0)$

$42.4(33.3-50.8)$

$41.7(33.3-50.7)$

$32.6(25.0-40.2)$

$25.0(17.4-31.8)$

$25.0(18.2-33.3)$

$15.2(9.8-22.0)$

$14.4(9.1-20.5)$

$13.6(8.3-19.7)$ 


\section{KJIM}

\section{Table 2 . Continued}

\begin{tabular}{|c|c|}
\hline Variable & $\%(95 \% \mathrm{CI})$ \\
\hline Drugs for treatment (e.g., chloroquine, remdesivir, etc.) & $12.9(7.6-18.9)$ \\
\hline Diagnostic equipment & $5.3(1.5-9.8)$ \\
\hline Hand sanitizer & $1.5(0-3.8)$ \\
\hline \multicolumn{2}{|c|}{ Q2. Necessity and possibility of reuse of $\mathrm{N}_{95}$ respirators within medical institutions in the case of a shortage } \\
\hline Necessary and possible & $32.6(25 \cdot 0-41.6)$ \\
\hline Necessary and impossible & $42.4(34.1-50.8)$ \\
\hline Not necessary and possible & $3.8(0.8-7.6)$ \\
\hline Not necessary and impossible & $17.4(11.4-24.2)$ \\
\hline \multicolumn{2}{|l|}{ Q3. Prioritization of patients in the case of a shortage of ventilators } \\
\hline Severity of the disease & $21.2(14.4-28.8)$ \\
\hline Probability of recovery & $47.0(38.6-56.0)$ \\
\hline Life expectancy & $22.0(15 \cdot 2-29 \cdot 5)$ \\
\hline Hospital arrival order & $2.3(0-5 \cdot 3)$ \\
\hline Not sure (difficult to answer) & $6.1(2.3-10.6)$ \\
\hline \multicolumn{2}{|l|}{$\begin{array}{l}\text { Q4 }{ }^{\mathrm{b}} \text {. Key areas of research and development to encourage in preparation for a further spread } \\
\text { of the COVID-19 pandemic }\end{array}$} \\
\hline Development of an effective vaccine & $75.0(67.4-82.6)$ \\
\hline Development of an effective therapeutic agent & $56.8(47 \cdot 7-65.2)$ \\
\hline Development of rapid and accurate diagnostic testing methods & $52.3(43.2-61.4)$ \\
\hline Development of an effective epidemiological investigation system & $32.6(24.2-40.2)$ \\
\hline Establishing a clinical trial system that can verify reported therapeutic agents or new drugs & $28.8(21.2-37.1)$ \\
\hline Development of mass supply methods for convalescent plasma from cured patients & $16.7(10.6-23.5)$ \\
\hline Development of an effective self-isolation monitoring tool & $12.9(7.6-18.9)$ \\
\hline Establishing a system for virus segregation & $10.6(6.1-16.7)$ \\
\hline Development of an effective protective gear & $9.8(4 \cdot 5-15 \cdot 9)$ \\
\hline Establishing animal experimental models that can verify reported therapeutic agents or new drugs & $4.6(1.5-8.3)$ \\
\hline \multicolumn{2}{|l|}{ Q5 ${ }^{\mathrm{a}}$. Important policies to be implemented at the national level in preparation for another outbreak } \\
\hline Securing national hospitals designated for the treatment of infectious diseases & $67.4(59.1-75.8)$ \\
\hline Strengthening immigration or prohibiting entry from countries with an outbreak & $65.9(57 \cdot 6-73 \cdot 5)$ \\
\hline Maintaining social distancing & $46.2(37.9-55 \cdot 3)$ \\
\hline Establishing a system for participation of private medical institutions/personnel in outbreaks & $45 \cdot 5(37 \cdot 1-53 \cdot 8)$ \\
\hline Reorganization of healthcare-related government & $22.7(15.9-30.3)$ \\
\hline Securing masks, hand sanitizers & $22.0(15.9-30.3)$ \\
\hline Securing community treatment centers & $18.9(12.9-25.8)$ \\
\hline Activation of online education/conference systems & $8.3(3.8-12.9)$ \\
\hline Full-fledge introduction of telemedicine & $3.0(0.8-6.1)$ \\
\hline \multicolumn{2}{|l|}{ Q6'. Screening of asymptomatic individuals using RT-PCR tests to prevent hospital outbreaks } \\
\hline Patients with a history of visiting areas with the outbreak & $88.6(82.6-93.9)$ \\
\hline All patients who require hospitalization & $36.4(28.8-44.7)$ \\
\hline All patients who need surgery & $27 \cdot 3(19 \cdot 7-35 \cdot 6)$ \\
\hline All patients who have recently been admitted to other hospitals & $29.5(22.0-37.1)$ \\
\hline
\end{tabular}


Table 2 . Continued

\begin{tabular}{|c|c|}
\hline Variable & $\%(95 \% \mathrm{CI})$ \\
\hline Medical staff treating COVID-19 patients & $31.1(23.5-38.6)$ \\
\hline Screening of asymptomatic individuals is not required & $12.1(6.8-17.4)$ \\
\hline \multicolumn{2}{|l|}{$\mathrm{Q}^{\mathrm{a}}$. Measures that should be upheld even after the end of the current outbreak } \\
\hline Thorough hand hygiene & $74.2(65.9-81.8)$ \\
\hline Avoiding public spaces if one shows symptoms of infections, such as fever & $70.5(62.9-78.0)$ \\
\hline Wearing masks in public & $56.8(47.7-65.2)$ \\
\hline Informing hospitals of recent visits to risk areas or recent contact with patients with COVID-19 & $40.2(32.6-48.5)$ \\
\hline Observe cough etiquette & $33 \cdot 3(25 \cdot 0-42.4)$ \\
\hline Maintaining a 2-meter distance & $25.0(18.2-32.6)$ \\
\hline Use of personal items, such as towels, tableware, mobile phones, etc. & o \\
\hline \multicolumn{2}{|l|}{ Q8. The best type of mask for use by the general public on a daily basis } \\
\hline $\mathrm{KF}_{94}$ (or N95) mask & $13.6(8.3-19.7)$ \\
\hline KF8o mask & $24.2(16.7-31.8)$ \\
\hline Surgical mask & $53.8(45 \cdot 5-62.1)$ \\
\hline Face mask & $3.8(0.8-6.8)$ \\
\hline Not recommended & $3.8(0.8-6.8)$ \\
\hline The treatment of COVID-19 & 127 \\
\hline \multicolumn{2}{|l|}{ Q1 ${ }^{\mathrm{b}}$. Drugs that may be effective for the treatment of COVID-19 } \\
\hline Remdesivir & $81.1(74.0-88.2)$ \\
\hline Convalescent plasma & $66.9(59.1-74.8)$ \\
\hline Hydroxychloroquine or chloroquine & $49.6(40.2-58.3)$ \\
\hline Anti-HIV drugs (e.g., lopinavir/ritonavir) & $39.4(31.5-47.2)$ \\
\hline Systemic corticosteroid & $22.8(15 \cdot 0-30.7)$ \\
\hline IL-6 pathway inhibitors (e.g., tocilizumab) & $15.7(9.4-22.0)$ \\
\hline Macrolides (e.g., azithromycin) & $12.6(7.1-18.9)$ \\
\hline Inhaled corticosteroid (e.g., ciclesonide) & $10.2\left(5 \cdot 5^{-15 \cdot 7)}\right.$ \\
\hline Interferon & $1.6(0-3 \cdot 9)$ \\
\hline Oseltamivir & o \\
\hline \multicolumn{2}{|l|}{ Q2. Patients to be treated with hydroxychloroquine or chloroquine } \\
\hline Q2-1. Asymptomatic, age < 6o years, no underlying disease & $26.8(19.7-34.6)$ \\
\hline Q2-1. Moderate symptoms without pneumonia, age < 60 years, no underlying disease, $\mathrm{SpO}_{2}>95 \%$ & $55.9(47 \cdot 2-64.6)$ \\
\hline Q2-2. Moderate symptoms without pneumonia, age $\geq 60$ years, no underlying disease, $\mathrm{SpO}_{2}>95 \%$ & $70.9(63.0-79.5)$ \\
\hline Q2-3. Existence of pneumonia, $\mathrm{SpO}_{2}>95 \%$ & $70.1(61.4-78.0)$ \\
\hline Q2-4. Existence of pneumonia requiring oxygen therapy & $73.2(65.4-81.1)$ \\
\hline Q2-5. The prevention of COVID-19 in elderly and patients with underlying diseases after exposure & $37.8(29.1-45 \cdot 7)$ \\
\hline Q2-6. The prevention of COVID-19 in medical staff treating COVID-19 patients & $22.8(15.7-29.9)$ \\
\hline \multicolumn{2}{|l|}{ Q3. The appropriate duration of a hydroxychloroquine or chloroquine treatment regimen } \\
\hline Within 5 days & $7.1(3.1-11.8)$ \\
\hline $5-7$ days & $40.9(32.3-48.8)$ \\
\hline $8-10$ days & $24.4(17 \cdot 3-32.3)$ \\
\hline $11-14$ days & $14.2(7.9-20.5)$ \\
\hline $15-21$ days & $1.6(0-3.9)$ \\
\hline
\end{tabular}


Table 2 . Continued

\begin{tabular}{|c|c|}
\hline Variable & $\%(95 \% \mathrm{CI})$ \\
\hline Until negative conversion of virus detection & $3.9(0.8-7.9)$ \\
\hline Miscellaneous & 132 \\
\hline \multicolumn{2}{|l|}{$\mathrm{Q}^{\mathrm{b}}{ }^{\mathrm{b}}$ Important issues that require urgent resolution } \\
\hline Determining the actual efficacy of existing or new drugs in the treatment of COVID-19 & $63.6(55 \cdot 3-71.2)$ \\
\hline The possibility of re-infection or the reactivation of the virus after patient recovery & $59.1(50.8-67.4)$ \\
\hline The conditions underlying infection transmission (e.g., period of infection propagation) & $53.8(44.7-62.9)$ \\
\hline The isolation criteria (e.g., inspection before release from isolation) & $36.4(28.0-44.7)$ \\
\hline Efficacy of protective gear in preventing infection & $30.3(22.0-38.6)$ \\
\hline Accuracy of existing diagnostic testing methods, including RT-PCR testing & $25.8(18.9-32.6)$ \\
\hline Selection criteria for individuals to be examined and tested & $15.9(9.8-22.7)$ \\
\hline Effectiveness of preventive medicine in the prevention of infection & $15.2(9.1-22.0)$ \\
\hline
\end{tabular}

COVID-19, coronavirus disease 2019; CI, confidence interval; PAPR, powered air purifying respirator; RT-PCR, real-time reverse-transcriptase polymerase chain reaction; HIV, human immunodeficiency virus; IL-6, interleukin 6.

${ }^{\text {a }}$ The time of conducting the survey (from April 21 to 25).

${ }^{b}$ This question requested the respondent to select the three most important items.

${ }^{\circ}$ This question requested the respondent to select multiple items.

The respondents stated that issues requiring urgent attention and resolution included "determining the actual efficacy of existing or new drugs for the treatment of COVID-19" (63.6\%), "the possibility of re-infection or the reactivation of the virus after patient recovery" (59.1\%), and "the conditions underlying the infection transmission" (53.8\%).

\section{The comparison in opinions on the preparation for} another COVID-19 outbreak as per the attending physician's experience in treating COVID-19 patients Most ID specialists who had experience in treating COVID-19 patients answered that powered air purifying respirator equipment (44.4\% vs. $7.1 \%$ ) are important items for hospitals in preparation for a second wave compared with those who had no experience in treating COVID-19 patients (Supplementary Table 1).

\section{DISCUSSION}

This survey highlights the opinions of Korean ID experts on controversial COVID-19-related issues. The opinions of these experts regarding emerging IDs are especially valuable as: (1) their opinions are based on their direct experience; (2) a relatively long time is needed to obtain scientific evidence on diseases; and (3) their opinions provide a guide for improving public preparedness. Our results provide useful information in preparation for another potential future COVID-19 outbreak.

In contrast to the positive social atmosphere in South Korea, many ID specialists do not envisage the current outbreak to be controlled easily. Considering the high viral load at the initial phase of the disease, even in asymptomatic patients [6], the complete control of viral transmission remains a challenge. Once social interactions between individuals return to normal and international travel is reinstated, the possibility of a COVID-19 second wave in South Korea is likely to increase accordingly.

The N95 respirators were considered as the most important item to be procured in hospitals. Since SARSCoV-2 is transmitted via the respiratory tract, health workers when caring for patients must use appropriate masks. In particular, the use of N95 respirators is an effective measure to protect healthcare personnel from the transmission of the virus during aerosol-generating procedures [9]. Unfortunately, hospitals experienced a lack of protective equipment in the middle of the outbreak, which is representative of the difficult experience 
of South Korea in dealing with the pandemic. In addition, experience might lead the majority of respondents to believe that the reuse of $\mathrm{N}_{95}$ respirators would be inevitable in the case of a shortage.

Many ID specialists believe that at the national level, securing hospitals designated specifically for the treatment of IDs is necessary. This may help to provide an effective therapy to COVID-19 patients, as well as protecting non-infectious patients admitted to other hospitals. Indeed, preventive measures against the inflow of COVID-19 into hospitals are fundamentally important since COVID-19 could be fatal when transmitted to in-patients [10]. Policymakers should consider this when establishing policies related to COVID-19.

The most important social measures to be upheld even after the end of the outbreak were hand hygiene and avoiding public places when a person has symptoms of infections. Given that the microorganisms are frequently transmitted via one's hand to another or themselves, hand hygiene is considered to be the single most important measure in reducing the transmission of microorganisms [11]. Given the fact that the dissemination of SARS-CoV-2 cannot be prevented just by wearing a mask and the virus can remain viable and infectious on surfaces up to days, hand hygiene should be emphasized to prevent infection $[12,13]$. Furthermore, interestingly, due to the thorough adherence to measures for the prevention of microorganism transmission, we witnessed that the incidence of other notorious transmissible IDs such as chickenpox, influenza, epidemic conjunctivitis, etc., decreased significantly in 2020 compared to other years [14]. People need to understand that not only the individual's health but also the health of the entire society could be protected with adherence to these measures.

As study results about the effectiveness of drugs tested for the treatment of COVID-19 have been released, opinions about the therapeutic option also have been converging accordingly. Since hydroxychloroquine or chloroquine was still one of the most promising therapeutic agents at the time of the survey period, we surveyed the opinion about the use of hydroxychloroquine or chloroquine in more detail. Unfortunately, the recent studies revealed that the use of hydroxychloroquine or chloroquine in COVID-19 might not be effective [15]. The only drug that showed effectiveness against COVID-19 to the date (June 5,2020 ) is remdesivir. It shortened the time of recovery in patients with COVID-19 and evidence of lower respiratory tract infection but it did not lower the mortality [16].

This study had some potential limitations. First, the response rate was approximately 50\% and those who were interested in such a study might tend to have responded to the survey. In order to minimize the selection bias, we sent reminders three times as well as offered the online link via both smartphones and computers to ease the access to the survey. Moreover, the demographic data of respondents (age $42.8 \pm 6.6$; female sex 57.6\%) were similar to those of the entire target population (age $44.7 \pm 6.7$; female sex 50.6\%) and the possibility of selection bias would not have been high. Second, some items might be interpreted differently by respondents due to the nature of the survey study.

In conclusion, many Korean ID experts believe that the COVID-19 pandemic will not be easily controlled and that a second nationwide wave is likely to occur in Korea. The country's preparedness in various aspects, including the provision of personal protective equipment in hospitals, will be necessary in order to deal with a potential future outbreak efficiently.

\section{KEY MESSAGE}

1. The highest proportion of the Korean infectious disease specialists envisaged the current coronavirus disease 2019 (COVID-19) outbreak to end after December 2020

2. N95 respirators were considered to be the most important item in hospitals while securing hospitals designated specifically for the treatment of infectious diseases was the most important policy to be implemented at the national level.

3. The respondents stated that the most important measures to be upheld by the public after the end of the outbreak were thorough hand hygiene and avoiding public spaces if one has symptoms of COVID-19.

\section{Conflict of interest}

No potential conflict of interest relevant to this article was reported. 


\section{Acknowledgments}

We would like to acknowledge all the respondents for their participation in the survey. The authors are also grateful to the Korean Society of Infectious Disease for identifying the target participants for the survey; Editage (www.editage.co.kr) for English language editing; Han-Pyo Hong (Biostatistics Collaboration Unit, Industry-University Cooperation Foundation, Hanyang University) for statistical analysis

\section{REFERENCES}

1. World Health Organization (WHO). WHO coronavirus disease (COVID-19) dashboard [Internet]. Geneva (CH): WHO, 2020 [cited 2020 Sep 8]. Available from: https:// covid19.who.int/.

2. Kim JY, Choe PG, Oh Y, et al. The first case of 2019 novel coronavirus pneumonia imported into Korea from Wuhan, China: implication for infection prevention and control measures. J Korean Med Sci 2020;35:e61.

3. Korean Center Disaster Management Headquarters. COVID-19 cases in Korea [Internet]. Sejong (KR): MOHW, 2020 [cited 2020 Sep 8]. Available from: http://ncov.mohw. go.kr/en/.

4. Korean Society of Infectious Diseases; Korean Society of Pediatric Infectious Diseases; Korean Society of Epidemiology; Korean Society for Antimicrobial Therapy; Korean Society for Healthcare-associated Infection Control and Prevention; Korea Centers for Disease Control and Prevention. Report on the epidemiological features of coronavirus disease 2019 (COVID-19) outbreak in the Republic of Korea from January 19 to March 2, 2020. J Korean Med Sci 2020;35:e112.

5. Luo Y, Trevathan E, Qian Z, et al. Asymptomatic SARS-CoV-2 infection in household contacts of a healthcare provider, Wuhan, China. Emerg Infect Dis 2020;26:1930-1933.

6. Zou L, Ruan F, Huang M, et al. SARS-CoV-2 viral load in upper respiratory specimens of infected patients. N Engl J
Med 2020;382:1177-1179.

7. Kim ES, Chin BS, Kang CK, et al. Clinical course and outcomes of patients with severe acute respiratory syndrome coronavirus 2 infection: a preliminary report of the first 28 patients from the Korean cohort study on COVID-19. J Korean Med Sci 2020;35:e142.

8. Sermo. COVID-19 real-time barometer study [Internet]. New York (NY): Sermo, 2020 [cited 2020 Sep 8]. Available from: https://app.sermo.com/covidı-barometer.

9. Center for Disease Control and Prevention. Interim infection prevention and control recommendations for patients with confirmed 2019 novel coronavirus (2019-nCoV) or patients under investigation for $2019-\mathrm{nCoV}$ in healthcare settings [Internet]. Atlanta (GA): CDC, 2020 [cited 2020 Sep 8]. Available from: https://www.cdc.gov/coronavirus/2019-nCoV/ hcp/infection-control.html.

10. McMichael TM, Currie DW, Clark S, et al. Epidemiology of COVID-19 in a long-term care facility in King County, Washington. N Engl J Med 2020;382:2005-2011.

11. Pittet D, Allegranzi B, Sax H, et al. Evidence-based model for hand transmission during patient care and the role of improved practices. Lancet Infect Dis 2006;6:641-652.

12. Bae S, Kim MC, Kim JY, et al. Effectiveness of surgical and cotton masks in blocking SARS-CoV-2: a controlled comparison in 4 patients. Ann Intern Med 2020;173:W22-W23.

13. van Doremalen N, Bushmaker T, Morris DH, et al. Aerosol and surface stability of SARS-CoV-2 as compared with SARS-CoV-1. N Engl J Med 2020;382:1564-1567.

14. Korea Centers for Disease Control and Prevention. Infectious disease portal [Internet]. Cheongju (KR): KCDC, 2020 [cited 2020 Sep 8]. Available from: http://www.cdc.go.kr/ npt/biz/npp/nppMain.do.

15. Boulware DR, Pullen MF, Bangdiwala AS, et al. A randomized trial of hydroxychloroquine as postexposure prophylaxis for Covid-19. N Engl J Med 2020;383:517-525.

16. Beigel JH, Tomashek KM, Dodd LE, et al. Remdesivir for the treatment of Covid-19: preliminary report. N Engl J Med 2020 May 22 [Epub]. https://doi.org/10.1056/NEJMoa2007764. 


\section{Supplementary material 1 . The questionnaire of the survey}

\section{A. English version \\ A survey on the opinion of Korean infectious diseases specialists regarding COVID-19}

The Korean Society of Infectious Diseases wishes to collect information on the opinions of infection experts on controversial issues related to the current COVID-19 pandemic. The data collected will be used to propose policies related to COVID-19 at the academic level, in response to the press, and promote them to the public. The survey is anonymous and without monetary reward. Its completion takes about 5 minutes, and the participation of personnel other than infectious diseases specialists (excluding fellows in training) is limited.

\section{o. Agreement to participate in the survey}

Would you agree to participate in this survey (a survey on the opinion of Korean infectious diseases specialists regarding COVID-19)?
口 Yes
$\square$ No

\section{Information about responder and affiliated hospital}
1-1. Sex
口 Male
๑ Female
1-2. Age
years old)

1-3. Year of the acquisition of the infectious diseases board?

1-4. Please indicate your position (choose one)

$\square$ Director of the clinical department

$\square$ Other )

1-5. What type of medical institution do you work for?
$\square$ Tertiary-care hospital
$\square$ Secondary-care hospital
$\square$ Hospital

$\square$ Clinic

1-6. Which of the following is the medical institution where you work?
$\square$ National university-affiliated hospital
$\square$ Private university-affiliated hospital
๑ Public Hospital; Not university-affiliated
๑ Private hospital; Not university-affiliated

$\square$ Other (

1-7. Please select the size of the medical institution you work for.
$\checkmark$ Less than 300 beds
口 300-60o beds
$\square$ 600-900 beds
$\square$ 900-1200 beds
$\square 1200$ beds or more

1-8. Does the hospital where you work run a state-designated negative-pressure isolation unit?

$\square$ Yes $\square$ No

1-9. Where do you work?
$\square$ Seoul
口 Incheon
$\square$ Gyeonggi-do
$\square$ Daegu
口 Ulsan
๑ Gyeongsangnam-do
- Gyeongsangbuk-do
$\square$ Daejeon/Sejong
$\square$ Chungcheongnam-do
๑ Chungcheongbuk-do
- Gwangju
口 Jeollanam-do
$\square$ Jeollabuk-do
$\square$ Gangwon-do
$\square$ Jeju-do

$\square$ Busan

1-10. How many infectious diseases specialists are there in the hospital where you work?

1-11. How many COVID-19 confirmed patients have you treated so far as an attending physician? (including patients who have been dispatched to a living and treatment support center or other institution)
$\square$ Less than 10
口 10-30
व $30-50$
口 50-100
100-200
200-300
$\square 300+$
- Not applicable 


\section{Opinions on COVID-19-related issues}

$<$ Prospects of COVID-19 outbreak>

2-1. When do you expect the current domestic COVID-19 epidemic to end?
口 May 2020
$\square$ June 2020
$\square$ July-August 2020
$\square$ September-October 2020
口 November-December 2020
After December 2020

2-2. When do you expect the current global COVID-19 pandemic to end?
$\square$ May 2020
$\square$ June 2020
๑ July-August 2020

$\square$ September-October 2020

$\square$ November-December 2020

After December 2020

2-3. Do you expect a nationwide second wave to occur in Korea?
$\square$ Very unlikely
๑ unlikely
口 Some likelihood
口 likely
$\square$ Very likely

2-4. When do you expect a nationwide second wave to occur in the country?
口 May 2020
$\square$ June 2020
$\square$ July-August 2020
$\square$ September-October 2020
口 November-December 2020
$\square$ After December 2020

$\square$ Answered the previous question as unlikely or very unlikely

2-5. How long do you think we should maintain our strategy to prevent inflow into hospitals (COVID-19 screening clinics, safe clinics for respiratory patients, pre-emptive isolation for pneumonia, etc.)?
口 May 2020
$\square$ June 2020
口 July-August 2020
口 September-October 2020
$\square$ November-December 2020
$\square$ After December 2020

2-6. How much more social distancing do you think is needed to prevent COVID-19 transmission?
$\square$ No longer needed
$\square$ Within two weeks from now
口 Within three to four weeks from now
口 Within 5-6 weeks from now
$\square$ Within 7-8 weeks from now
口 More than 8 weeks from now

$<$ Preparation for future COVID-19 outbreak>

2-7. In the event of a second wave, please select 3 items that you believe will be lacking in medical institutions and that will need to be prepared in advance.

$\square$ Hooded coveralls $\square$ N95 respirators/masks $\square$ PAPR equipment (including hoods)

$\square$ Other protective gear (goggles, hair caps, etc.) $\quad$ \ Hand sanitizer

$\square$ Isolation units (including negative-pressure units)

$\square$ Equipment for oxygen supplementation (including ventilators, high-flow $\mathrm{O}_{2}$ )

$\square$ Professional physicians for COVID-19

$\square$ Professional nursing personnel for COVID-19 $\square$ Diagnostic equipment

$\square$ Infection control personnel

$\square$ Drugs for treatment (chloroquine, remdesivir, etc.)

2-7-1. Please describe any items not included above that you think will be necessary. (

2-8. Do you think it is necessary or possible to reuse N95 masks within a medical institution in the case of a shortage?

$\square$ I think reuse is necessary and possible

口 I think reuse is necessary but I don't think it's possible

$\square$ Reuse is not necessary, but I think it is possible

$\square$ Reuse is not necessary and is not possible

$\square$ Not sure

2-9. If a shortage of ventilators occurs, what criteria should be used to prioritize patients?
$\square$ Severity of the disease
口 Probability of recovery
$\square$ Life expectancy
$\square$ Hospital arrival order
$\square$ Social role (e.g. leaders, professionals, etc.)
$\square$ Not sure
$\square$ Tax payment degree 
2-10. Taking into account the domestic situation, what area of research and development do you believe needs to be fostered in preparation for further spreading of COVID-19? Please select 3 items.

$\square$ Development of an effective epidemiological investigation system

$\square$ Development of an effective self-isolation monitoring tool

$\square$ Development of an effective protective gear

$\square$ Development of rapid and accurate diagnostic testing methods

$\square$ Development of an effective drug for treatment

$\square$ Development of an effective vaccine

$\square$ Development of mass supply methods for convalescent plasma from cured patients

- Establishing animal experimental models that can verify reported therapeutic agents or new drugs

- Establishing a clinical trial system that can verify reported therapeutic agents or new drugs

- Establishing a system for virus segregation

2-10-1. Please describe any items not included above that you think are necessary.

2-11. Choose 3 policies that you believe should be implemented at the national level to prevent/prepare for another COVID-19 outbreak in the future.

$\square$ Securing living and treatment support centers

$\square$ Securing national hospitals designated for the treatment of infectious disease

$\square$ Strengthening immigration or prohibiting entry from countries in the outbreak

$\square$ Maintaining social distancing

$\square$ Securing masks and hand sanitizer

๑ Reorganizing healthcare-related government

$\square$ Activation of online education/conference systems

$\square$ Full-fledged introduction of telemedicine

口 Establishing a system for participation of private medical institutions/medical personnel in outbreaks

2-11-1. Please describe any items not included above that you think are necessary. (

2-12. Which of the following profiles do you believe will require screening with RT-PCR tests to prevent COVID-19 outbreaks in medical institution in cases where an individual does not have any symptoms? Please select all items which you think necessary.

$\square$ Patients with a history of visiting affected or at-risk areas

$\square$ All patients who require hospitalization

$\square$ All patients who need surgery

$\square$ All patients who have recently been admitted to other hospitals

$\square$ Medical staff treating patients with COVID-19

$\square$ Screening for asymptomatic individuals is not required

$\square$ Other

2-13. After the end of the current pandemic, what measures do you believe should be upheld to prevent another outbreak? Please select 3 items.

$\square$ Maintaining a 2 meter distance from others

$\square$ Wearing masks in public places

$\square$ Avoiding public spaces if symptoms of infection develop, such as fever

口 Thorough hand hygiene

$\square$ Use of personal items, such as towels, tableware, mobile phones, etc.

$\square$ Observing cough etiquette

- Informing hospitals of recent trips to at-risk areas or contact with infected patients before a hospital visit

2-13-1. Please describe any items not included above that you think are necessary.

2-14. What type of mask do you recommend should be worn by the public in daily life, including when visiting 

public places?
口 KF94 (or N95) mask
口 KF8o mask
口 Surgical mask
$\square$ Face mask
$\checkmark$ Not recommended

$<$ Treatment for COVID-19>

2-15. Choose 3 drugs you believe will be the most effective in treating COVID-19 patients.

- Hydroxychloroquine or chloroquine

$\checkmark$ Macrolides (including azithromycin)

口 Anti-HIV drugs (including lopinavir/ritonavir)

$\square$ Remdesivir

$\checkmark$ Oseltamivir

口 Interferon

$\square$ Convalescent plasma

$\square$ Systemic corticosteroid

$\square$ Inhaled corticosteroid (including ciclesonide)

口 IL-6 pathway inhibitors (including tocilizumab)

2-15-1. Please describe any items not included above that you think are necessary.

2-16. Would you recommend administering hydroxychloroquine or chloroquine to asymptomatic patients under the age of 60 who have no underlying diseases?
$\square$ Yes
$\square$ No

2-17. Would you recommend administering hydroxychloroquine or chloroquine to patients with moderate symptoms without pneumonia under 60 years of age without underlying disease, $\mathrm{SpO}_{2}>95 \%$ ?

$\square$ Yes $\square$ No

2-18. Would you recommend administering hydroxychloroquine or chloroquine to patients with moderate symptoms with underlying diseases or no pneumonia over 60 years of age, $\mathrm{SpO}_{2}>95 \%$

$\square$ Yes $\quad$ No

2-19. Would you recommend administering hydroxychloroquine or chloroquine to patients with pneumonia, $\mathrm{SpO}_{2}>95 \%$ ?

$\square$ Yes $\square$ No

2-20. Would you recommend administering hydroxychloroquine or chloroquine to patients with pneumonia requiring oxygen therapy?

$\square$ Yes $\square$ No

2-21. Would you recommend administering hydroxychloroquine or chloroquine to prevent of COVID-19 in elderly patients with underlying diseases after exposure in the hospital?
$\square$ Yes
$\square$ No

2-22. Would you recommend administering hydroxychloroquine or chloroquine to prevent COVID-19 in medical staffs treating COVID-19 patients?
$\square$ Yes
$\square$ No

2-23. If administering hydroxychloroquine or chloroquine, what do you believe the duration of the regimen should be to be effective in treating patients?
$\square$ Within 5 days
口 5-7 days
$\square$ 8-10 days
口 11-14 days
$\square$ 15-21 days
22-28 days
$\square$ Until negative conversion of virus detection

$<$ Miscellaneous>

2-24. Which of the following COVID-19 issues do you think requires urgent attention? Please select 3 items.

$\square$ Determining the actual efficacy of existing or new drugs in the treatment of COVID-19

$\square$ Accuracy of existing diagnostic testing methods, including RT-PCR testing

$\square$ The possibility of re-infection or the reactivation of the virus after patient recovery

$\square$ Effectiveness of preventive medication in the prevention of infection

$\square$ Selection criteria for individuals to be examined and tested 
$\square$ Efficacy of protective gear in preventing infection

口 The isolation criteria (e.g. inspection before release from isolation)

$\square$ The conditions underlying the infection transmission (e.g. period of infection propagation) 2-24-1. Please describe any items not included above that you think are necessary. 


\section{KJIM}

\section{B. Korean version}

\section{COVID-19에 대한 국내 감염 전문가 견해 조사}

대한감염학회에서는 많은 논란이 되고 있는 COVID-19 관련 이슈에 대한 감염 전문가들의 의견을 취합하고자 합니다. 취합된 자료는 향후 학회 차원의 COVID-19 관련 정책 제안, 언론 대응, 대국민 홍보 등에 활용할 예정입니다. 본 설문조사는 개인식별정보를 익명화 하여 보호하고 생명윤리 및 안전에 관한 법률에 따라 설문조사자료는 보관 및 폐기될 예정입니다. 설문조사에 따른 금전적 보상은 없으 며 약 10 분이 소요될 것으로 예상되며 감염내과 분과전문의(수련 중인 fellow 제외) 이외 인력의 참여는 제한됩니다.

\section{0. 설문조사 참여 동의}

0-1. 본 설문 조사(COVID-19에 대한 국내 감염 전문가 견해 조사)에 참여하는 것에 동의하십니까?
$\square$ 예
$\square$ 아니오

\section{1. 설문조사 응답 인력 기본 정보}
1-1. 성별
$\square$ 남성
1-2. 연령
(만
$\square$ 여성

1-3. 감염내과 분과 전문의 취득 년도는 언제입니까? (

1-4. 선생님의 직위에 해당하는 항목을 표시해 주십시오(복수 응답)
$\square$ 진료과장
$\square$ 감염관리부서장
$\square$ 병원내 기타 보직자(
$\square$ 해당사항 없음
1-5. 선생님이 근무하시는 의료기관의 유형은 무엇입니까?
$\square$ 상급종합병원 $\square$ 종합병원
$\square$ 병원
의원
1-6. 선생님이 근무하시는 의료기관은 아래 중 어디에 해당합니까?

$\begin{array}{lll}\square \text { 국공립 대학병원 } & \square \text { 사립 대학병원 } & \square \text { 공공병원-비대학병원 } \\ \square \text { 민간병원-비대학병원 } & \square \text { 기타( } & \\ 1-7 . \text { 선생님이 근무하시는 의료기관의 규모를 선택해 주십시오 } & \\ \square 300 \text { 병상 미만 } & \square \text { 300-600병상 } & \square 600-900 \text { 병상 } \\ \square 900-1200 \text { 병상 } & \square \text { 1200병상 이상 } & \end{array}$

1-8. 선생님이 근무하는 병원은 국가지정 음압치료병상을 운영하고 있습니까?
$\square$ 예
$\square$ 아니오

1-9. 선생님의 근무 지역은 어디입니까?

$\begin{array}{lll}\square \text { 서울 } & \square \text { 인천 } & \square \text { 경기도 } \\ \square \text { 부산 } & \square \text { 대구 } & \square \text { 울산 } \\ \square \text { 경상남도 } & \square \text { 경상북도 } & \square \text { 대전/세종 } \\ \square \text { 충청남도 } & \square \text { 충청북도 } & \square \text { 광주 } \\ \square \text { 전라남도 } & \square \text { 전라북도 } & \square \text { 강원도 } \\ \square \text { 제주도 } & \end{array}$

1-10. 선생님이 근무하는 병원에는 감염내과 분과 전문의가 총 몇 명입니까?

1-11. 선생님께서 지금까지 주치의나 담당의로 진료한 COVID-19 확진 환자의 수는 몇 명입니까? (생활치료센터나 타 기관에 파견 되어 진료한 환자를 포함합니다)
$\square 10$ 명 미만
$\square$ 10-30명
$\square$ 30-50명
50-100명
$\square$ 100-200명
$\square$ 200-300명
$\square$ 300명 이상 


\section{COVID-19 관련 이슈에 대한 의견}

\section{$<C O V I D-19$ 유행 전망>}

2-1. 현재의 국내 COVID-19 유행이 언제쯤 종식 될 것으로 예상하시는지요?

$\begin{array}{lll}\square \text { 2020년 5월중 } & \square \text { 2020년 6월중 } & \square \text { 2020년 7-8월중 } \\ \square \text { 2020년 9-10월중 } & \square \text { 2020년 11월-12월중 } & \square \text { 2020년 12월 이후 } \\ \text { 2-2. 현재의 세계 COVID-19 대유행이 언제쯤 종식 될 것으로 예상하시는지요? } & \\ \square \text { 2020년 5월중 } & \square \text { 2020년 6월중 } & \square \text { 2020년 7-8월중 } \\ \square \text { 2020년 9-10월중 } & \square \text { 2020년 11월-12월중 } & \square \text { 2020년 12월 이후 }\end{array}$

2-3. 전국적 규모의 대유행(second wave)이 국내에 발생할 것으로 예상하시는지요?
$\square$ 가능성이 매우 낮음
$\square$ 가능성이 낮음
$\square$ 가능성이 어느 정도 있음
$\square$ 가능성이 높음
$\square$ 가능성이 매우 높음

2-4. 전국적 규모의 대유행(second wave)이 언제 국내에 발생할 것으로 예상하시는지요?
$\square$ 2020년 5월중
$\square$ 2020년 6월중
$\square$ 2020년 7-8월중
$\square$ 2020년 9-10월중
$\square$ 2020년 11월-12월중
$\square$ 2020년 12월 이후

$\square$ 가능성이 매우 낮거나 매우 낮다고 생각함

2-5. 병원내 유입 방지를 위한 전략(선별진료소, 안심진료소, 폐렴 선제격리 등)을 언제까지 유지해야 한다고 생각하시는지요?
$\square$ 2020년 5월중
$\square$ 2020년 6월중
$\square$ 2020년 7-8월중
$\square$ 2020년 9-10월중
$\square$ 2020년 11월-12월중
$\square$ 2020년 12월 이후

2-6. COVID-19 전파 방지를 위해서 앞으로 얼마나 더 사회적 거리두기가 필요하다고 생각하시는지요?
$\square$ 더 이상 필요치 않음
$\square$ 지금부터 2주 이내
$\square$ 지금부터 3-4주 이내
$\square$ 지금부터 5-6주 이내
$\square$ 지금부터 7-8주 이내
$\square$ 지금부터 8주 이상

\section{<COVID-19 2차 유행 대비>}

2-7. 향후 2차 유행이 발생할 경우 의료기관 내에서 부족이 예상되어 미리 준비가 필요하다고 생각하시는 항목 1, 2, 3순위를 골라 주십시오.

$\square$ 전신보호복

$\square$ PAPR 장비(후드 포함)

$\square$ 격리병상(음압병상 포함)

$\square$ 전문 의사 인력

$\square$ 감염 관리 인력

2-7-1. 위의 문항에 포함되지 않은 항목 중 반드시 필요하다고 생각하시는 것이 있다면 자유롭게 기술하여 주십시오.

2-8. N95 마스크가 부족할 경우 의료기관 내에서 재사용이 필요 혹은 가능하다고 생각하십니까?

$\square$ 재사용이 필요하고 가능하다고 생각

$\square$ 재사용이 필요 없으나 가능하다고 생각

$\square$ 재사용이 필요하나 가능하지 않다고 생각

$\square$ 재사용이 필요 없고 가능하지 않다고 생각

\section{$\square$ 잘 모르겠음}

2-9. 만약 ventilator 부족 사태가 발생할 경우 어떤 기준에 따라 환자의 우선 순위를 정해야 한다고 생각하십니까?
$\square$ 질환의 중증도
$\square$ 회복 가능성
$\square$ 사회적 역할(e.g. 지도자, 전문직 등)
$\square$ 병원 도착 순서
$\square$ 기대 여명
세금 납부 정도

$\square$ 잘 모르겠음(답변이 어려움)

2-10. 국내 현황을 고려하였을 때 유행의 확산에 대비하기 위해 가장 중점적으로 육성해야 하는 연구 개발 정책 분야는 무엇이라고 생각하시는지요? 중요한 3가지를 골라 주십시오.

$\square$ 효과적인 역학 조사 시스템 개발

$\square$ 효과적인 보호구 개발

$\square$ 효과적인 치료약제 개발 
완치환자 혈장 제공 및 대량 공급방법 개발

$\square$ 보고되고 있는 치료물질이나 신약을 검증할 수 있는 동물실험모델 구축 및 활성화

$\square$ 보고되고 있는 치료물질이나 신약을 검증할 수 있는 임상시험체계 구축 및 활성화

$\square$ 바이러스 분리 배양을 위한 시스템 구축 및 활성화

2-10-1. 위의 문항에 포함되지 않은 항목 중 반드시 필요하다고 생각하시는 것이 있다면 자유롭게 기술하여 주십시오.

2-11. 향후 2차 유행 발생을 방지/대비하기 위해 국가 차원에서 수행이 필요하다고 생각하는 정책 3가지를 골라 주십시오.

$\square$ 생활치료센터 확보

$\square$ 위험지역국가에서의 입국심사 강화/입국금지

$\square$ 감염병 전담병원 확보

$\square$ 마스크, 손소독제 확보

$\square$ 사회적 거리두기 유지

$\square$ 화상 교육, 화상 회의 시스템 활성화

$\square$ 유행 상황에서 민간 의료기관/의료인 참여 관련 시스템 정립

2-11-1. 위의 문항에 포함되지 않은 항목 중 반드시 필요하다고 생각하시는 것이 있다면 자유롭게 기술하여 주십시오.

(

2-12. 다음 중 의료기관 내 유행을 방지하기 위하여 발열이나 호흡기 증상이 없더라도 스크리닝이 필요하다고 생각하는 대상은 무엇 입니까? (복수 응답)

$\square$ 국내 혹은 해외 유행지역 방문력이 있는 환자

$\square$ 입원이 필요한 모든 환자

$\square$ 수술이 필요한 모든 환자

$\square$ 최근 타병원 입원력이 있는 모든 환자

$\square$ 확진 환자 진료에 투입되는 의료진

$\square$ 상주 보호자(간병인 포함)

$\square$ 증상이 없는 환자 스크리닝은 필요치 않음

$\square$ 기타(

2-13. 현재의 유행이 종식되더라도 2차 유행 방지를 위해 필요하다고 생각하는 국민 생활 수칙은 무엇입니까? 중요한 3가지를 골라 주십시오.

$\square$ 일상에서 $2 \mathrm{~m}$ 거리 유지

$\square$ 발열 등 증상이 있을 경우 공공장소 방문 자제

$\square$ 수건, 식기류, 휴대전화 등 개인물품 사용

$\square$ 병의원 방문 시 진료 전 위험지역 방문력, 호흡기 질환자 접촉 여부를 알림.

2-13-1. 위의 문항에 포함되지 않은 항목 중 반드시 필요하다고 생각하시는 것이 있다면 자유롭게 기술하여 주십시오.

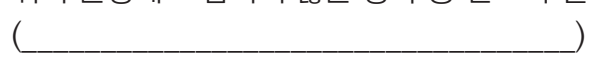

$\square$ 공공 장소에서 마스크 착용

$\square$ 철저한 손위생 준수

$\square$ 기침 예절 준수

2-14. 공공장소 방문을 포함한 일상 생활에서 착용을 권고하는 마스크 종류는 무엇입니까?

$\begin{array}{ll}\square \text { KF94 (혹은 N95) 마스크 } & \square \text { KF80 마스크 } \quad \square \text { 외과용 마스크 } \\ \square \text { 면 마스크 } & \square \text { 마스크 착용을 권고하지 않음 }\end{array}$

$\langle$ COVID-19 치료제〉

2-15. 다음 약제들 중 COVID-19 환자 치료에 가장 효과적일 것으로 생각되는 약물 3가지를 골라주십시오.

$\square$ Hydroxychloroquine or Chloroquine

$\square$ Anti-HIV drugs (Lopinavir/ritonavir 포함)

$\square$ Macrolides (azithromycin 포함)

$\square$ Oseltamivir

$\square$ 회복기 환자 혈장

$\square$ Remdesivir

$\square$ ciclesonide 등 흡입 스테로이드

Interferon

$\square$ 전신 스테로이드

IL-6 pathway inhibitors (tocilizumab 포함)

2-15-1. 위의 문항에 포함되지 않은 항목 중 치료에 효과적이라고 생각하시는 약물이 있다면 자유롭게 기술하여 주십시오.

2-16. 기저질환이 없는 60세 이하 무증상-경증 환자에게 hydroxychloroquine or chloroquine을 투여하시겠습니까?

$\square$ 예

$\square$ 아니오 
2-17. 기저질환이 없는 60세 이하 폐렴이 없는 중등도 증상 환자 $\left(\mathrm{SpO}_{2}>95 \%\right)$ 에게 hydroxychloroquine or chloroquine을 투여 하시겠습니까?

$\square$ 예 $\square$ 아니오

2-18. 기저질환이 있거나 60세 이상 폐렴이 없는 중등도 증상 환자 $\left(\mathrm{SpO}_{2}>95 \%\right)$ 에게 hydroxychloroquine or chloroquine을 투 여하시겠습니까?

$\square$ 예 $\quad \square$ 아니오

2-19. 폐렴이 있는 환자( $\left.\mathrm{SpO}_{2}>95 \%\right)$ 에게 hydroxychloroquine or chloroquine을 투여하시겠습니까?

$\square$ 예 $\square$ 아니오

2-20. 산소치료를 요하는 폐렴이 있는 환자에게 hydroxychloroquine or chloroquine을 투여하시겠습니까?

$\square$ 예 $\square$ 아니오

2-21. 원내 노출 후 고령 및 기저질환자에 대한 예방 목적으로 hydroxychloroquine or chloroquine을 투여하시겠습니까?

$\square$ 예 $\square$ 아니오

2-22. COVID-19 확진환자를 진료하는 의료진에 대한 예방 목적으로 hydroxychloroquine or chloroquine을 투여하시겠습니 까?

$\square$ 예 $\square$ 아니오

2-23. Hydroxychloroquine or chloroquine regimen을 사용한다면 어느 정도 기간 동안 투약하는 것이 환자 치료에 효과적이라 고 생각하십니까?
$\square 5$ 일 이내
$\square$ 15-21일
$\square 5-7$ 일
$\square$ 22-28일
$\square$ 8-10일
$\square$ 바이러스 음전 시점까지

$<$ 기타>

2-24. 다음 중 현재 국내 의료현장에서 시급한 정립 혹은 재정립이 필요할 것으로 생각하시는 COVID-19 이슈는 무엇입니까? 중요 한 3가지를 골라주십시오.

$\square$ 치료에 효과가 있을 수 있는 기존 약제나 신약들의 실제 효능

$\square \mathrm{PCR}$ 검사를 포함한 현존하는 진단 검사법의 정확성

$\square$ 완치 판정 후 바이러스 재감염 혹은 재활성화 가능성

$\square$ 감염 예방을 위한 예방적 약물 요법의 효능/효과

$\square$ 검사 대상의 선정 기준

$\square$ 감염 전파 예방을 위한 보호구 착용의 범위

$\square$ 격리 해제 기준(격리 해제를 위해 수행해야 하는 검사 시기 포함)

$\square$ 실제 감염을 일으킬 수 있는 조건(감염 전파력이 있는 기간, 경로 포함)

2-24-1. 위의 문항에 포함되지 않은 항목 중 반드시 필요하다고 생각하시는 것이 있다면 자유롭게 기술하여 주십시오. 
Supplementary Table 1. The comparison in opinions on preparation for future COVID-19 outbreak according to experience in treating COVID-19 patients as an attending physician

\begin{tabular}{|c|c|c|c|}
\hline Variable & $\begin{array}{l}\text { Existence, } \% \\
\qquad(\mathrm{n}=90)\end{array}$ & $\begin{array}{l}\text { Absence, } \% \\
\quad(\mathrm{n}=42)\end{array}$ & $\begin{array}{l}95 \% \text { CI of } \\
\text { Agresti-caffo }\end{array}$ \\
\hline \multicolumn{4}{|c|}{ Important items that will be needed in hospitals in preparation for a second wave of COVID-19 ${ }^{\mathrm{a}}$} \\
\hline N95 respirators & 68.9 & 73.8 & -0.12 to 0.21 \\
\hline Isolation units (including negative-pressure units) & 40.0 & $47 \cdot 6$ & -0.10 to 0.25 \\
\hline Hooded coveralls & 38.9 & $47 \cdot 6$ & -0.09 to 0.26 \\
\hline PAPR equipment (including hoods) & $44 \cdot 4$ & $7 \cdot 1$ & 0.19 to 0.52 \\
\hline Professional physician for COVID-19 & 30.0 & $14 \cdot 3$ & -0.01 to 0.30 \\
\hline Professional nursing personnel for COVID-19 & 26.7 & 21.4 & -0.11 to 0.20 \\
\hline Infection control personnel & $13 \cdot 3$ & 19.0 & -0.07 to 0.20 \\
\hline Other protective gear (goggles, hair caps, etc.) & $13 \cdot 3$ & 16.7 & -0.09 to 0.17 \\
\hline Equipment for oxygen supplementation (including ventilators, high-flow $\mathrm{O}_{2}$ ) & 8.9 & 23.8 & 0.02 to 0.28 \\
\hline Drugs for treatment (e.g., chloroquine, remdesivir, etc.) & 11.1 & 16.7 & -0.06 to 0.19 \\
\hline Diagnostic equipment & $4 \cdot 4$ & 7.1 & -0.05 to 0.13 \\
\hline Hand sanitizer & o & 4.8 & o to 0.12 \\
\hline \multicolumn{4}{|c|}{ Key areas of research and development to foster in preparation for the further spread of COVID-19 ${ }^{a}$} \\
\hline Development of an effective vaccine & 72.2 & 81.0 & -0.08 to 0.24 \\
\hline Development of an effective drug for treatment & $55 \cdot 6$ & $59 \cdot 5$ & -0.14 to 0.21 \\
\hline Development of rapid and accurate diagnostic testing methods & 48.9 & $59 \cdot 5$ & -0.08 to 0.28 \\
\hline Development of an effective epidemiological investigation system & $33 \cdot 3$ & 31.0 & -0.15 to 0.19 \\
\hline $\begin{array}{l}\text { Establishing a clinical trial system that can verify reported therapeutic } \\
\text { agents or new drugs }\end{array}$ & 32.2 & 21.4 & -0.06 to 0.26 \\
\hline $\begin{array}{l}\text { Development of mass supply methods for convalescent plasma from } \\
\text { cured patients }\end{array}$ & $14 \cdot 4$ & 21.4 & -0.06 to 0.21 \\
\hline Development of an effective self-isolation monitoring tool & $15 \cdot 6$ & 7.1 & -0.05 to 0.20 \\
\hline Establishing a system for virus segregation & 12.2 & 7.1 & -0.08 to 0.16 \\
\hline Development of an effective protective gear & 11.1 & 7.1 & -0.08 to 0.14 \\
\hline $\begin{array}{l}\text { Establishing animal experimental models that can verify reported } \\
\text { therapeutic agents or new drugs }\end{array}$ & $4 \cdot 4$ & 4.8 & -0.07 to 0.10 \\
\hline \multicolumn{4}{|c|}{ Important policies to be implemented at the national level in preparation for another outbreak ${ }^{\mathrm{a}}$} \\
\hline Securing national hospitals designated for the treatment of infectious diseases & 68.9 & $64 \cdot 3$ & -0.12 to 0.22 \\
\hline $\begin{array}{l}\text { Strengthening immigration or prohibiting entry from countries in the } \\
\text { outbreak }\end{array}$ & 66.7 & $64 \cdot 3$ & -0.14 to 0.20 \\
\hline Maintaining social distancing & 40.0 & $59 \cdot 5$ & 0.01 to 0.37 \\
\hline $\begin{array}{l}\text { Establishing a system for participation of private medical institutions/ } \\
\text { personnel in outbreaks }\end{array}$ & 47.8 & 40.5 & -0.11 to 0.25 \\
\hline Reorganization of healthcare-related government & 26.7 & $14 \cdot 3$ & -0.04 to 0.27 \\
\hline Securing masks, hand sanitizers & $23 \cdot 3$ & 19.0 & -0.12 to 0.19 \\
\hline Securing community treatment centers & 18.9 & 19.0 & -0.13 to 0.15 \\
\hline Activation of online education/conference systems & $4 \cdot 4$ & 16.7 & 0.02 to 0.23 \\
\hline Full-fledge introduction of telemedicine & $3 \cdot 3$ & 2.4 & -0.07 to 0.08 \\
\hline
\end{tabular}


Kim B, et al. Expert opinions on COVID-19

Supplementary Table 1. Continued

\begin{tabular}{|c|c|c|c|}
\hline Variable & $\begin{array}{l}\text { Existence, \% } \\
\quad(\mathrm{n}=90)\end{array}$ & $\begin{array}{l}\text { Absence, \% } \\
(\mathrm{n}=42)\end{array}$ & $\begin{array}{l}95 \% \text { CI of } \\
\text { Agresti-caffo }\end{array}$ \\
\hline \multicolumn{4}{|c|}{ Individuals without symptoms to be screened using RT-PCR tests to prevent hospital outbreaks ${ }^{\mathrm{b}}$} \\
\hline Patients with a history of visiting areas in the outbreak & 86.7 & 92.9 & -0.07 to 0.17 \\
\hline All patients who require hospitalization & 38.9 & 31.0 & -0.10 to 0.25 \\
\hline All patients who need surgery & 25.6 & 31.0 & -0.10 to 0.22 \\
\hline All patients who have recently been admitted to other hospitals & 30.0 & 28.6 & -0.16 to 0.17 \\
\hline Medical staff treating COVID-19 patients & 25.6 & 42.9 & o to 0.34 \\
\hline Screening for asymptomatic individuals is not required & 13.3 & 9.5 & -0.09 to 0.15 \\
\hline \multicolumn{4}{|l|}{ Measures that should be upheld even after the end of the current outbreak ${ }^{\mathrm{a}}$} \\
\hline Thorough hand hygiene & 74.4 & 73.8 & -0.15 to 0.17 \\
\hline Avoiding public spaces if one shows symptoms of infections, such as fever & 71.1 & 69.0 & -0.14 to 0.19 \\
\hline Wearing masks in public & 55.6 & $59 \cdot 5$ & -0.14 to 0.21 \\
\hline $\begin{array}{l}\text { Informing hospitals of recent visits to at-risk areas or recent contact } \\
\text { with COVID-19 patients }\end{array}$ & 38.9 & 42.9 & -0.14 to 0.22 \\
\hline Observe cough etiquette & 35.6 & 28.6 & -0.11 to 0.23 \\
\hline Maintaining a 2-meter distance & $24 \cdot 4$ & 26.2 & -0.13 to 0.18 \\
\hline Use of personal items, such as towels, tableware, mobile phones, etc. & $\circ$ & $\circ$ & - \\
\hline
\end{tabular}

COVID-19, coronavirus disease 2019; CI, confidence interval; PAPR, powered air purifying respirator; RT-PCR, real-time reverse-transcriptase polymerase chain reaction.

${ }^{a}$ This question requested the responder to select the three most important items.

${ }^{\mathrm{b}}$ This question requested the responder to select multiple items. 